\title{
Decision Support System Honorary Employee Performance Appraisal with TOPSIS method the Public Works Department and Spatial Deli Serdang
}

\begin{abstract}
Abel Tasman ${ }^{1}$, R. Mahdalena Simanjorang ${ }^{2}$
${ }^{1.2}$ Informatics Engineering Study Program, STMIK Pelita Nusantara, Jl. Iskandar Muda No. 1 Medan, North Sumatra,Indonesia 20154

E-mail: abeltasman1994@gmail.com

Abstract-Honorary employee performance appraisal on the Department of Public Works and Spatial Deli Serdang conducted on 10 honorary staff as samples of employee performance appraisal of data as material for consideration of the continuation of the cooperative relationship for the future budget. Components of employee performance appraisal onconducted on 10 honorary staff as samples of employee performance appraisal of data as material for consideration of the continuation of the cooperative relationship for the future budget. Components of employee performance appraisal on the Department of Public Works and Spatial Deli Serdang namely work performance, performance quantity, performance discipline, cooperation, and commitment. Problems with the employee performance appraisal process that occur due to unclear criteria and weight of the appraisal. A method in the decision support system can help the optimal decision making process that is TOPSIS method in Determining the performance appraisal of honorary employees. There are three employee performance weights, the which are very good, good, and quite good, from 10 employees Categorized by performance appraisal, after being applied with the TOPSIS method, Joko Suprapto Obtained value $=0.8394$ and Suhendra value $=0.7862$ both honorary employees are Categorized by assessment very good performance.
\end{abstract}

Keywords: Decision Support System (DSS), TOPSIS Method, Honorary Employees.

\section{Introduction}

Developments in information technology over the years that the sooner a challenge for the users themselves and to encourage every sector of both formal and informal organizations or other agencies to be able to use it as a support kenerja votes employees.

Department of Public Works and Spatial Power Deli Serdang have Honorer working were about 40 people. The biggest obstacle honorary implementation of performance assessment is the limited time and human resources involved in a long kinerjaWaktu ratings in assessing the ratio between the number of assessors is 19 (the head section): 40 (honorarium). Starting from the above-mentioned limitations needed a new system that can aid decision-making. Then the required supporting resources such as software that is reliable capabilities and human resources that have a good performance at the Department of Public Works and Spatial Deli Serdang.

\section{Theory}

\section{A. Decision Support System}

Kusrini (2017: 15) Decision Support System (DSS), is generally defined as a system that is capable of providing good ability and the ability of problem solving capability of communicating to the problem semiterstuktur. Specifically, CMS is defined as a system that supports the work of a manager or group of managers in a semistructured problem solving by providing information or suggestion towards the particular decision

\section{B. methods Tospsis}

TOPSIS is one of multiple criteria decision-making methods or alternative option is an alternative that has the smallest distance from the negative ideal solution from a geometrical point by using the Euclidean distance. However, the alternative that has the greatest distance from the negative ideal solution. Therefore, TOPSIS into account both the distance of the positive ideal solution and the distance to the negative ideal solution simultaneously. The optimal solution in TOPSIS method obtained by finding the relative proximity of a positive alternative to the ideal solution, TOPSIS to rank alternatives based on the priority value relative proximity to a alterantif idealpositif solution. Alternatives has been ranked then be used as a reference for decision makers to choose the best solution is desired.

Steps metdode TOPSIS is sebgai follows: 
1) Ranking each alternative

Technique For Order Preference by Similarity to Ideal Solution (TOPSIS) require performance ratings of each alternative () on each of the criteria () are normalized, namely: $A_{i} C_{j}$

$r_{i j}=\frac{x_{i j}}{m_{i=1}^{m} x_{i j}^{2}} \ldots$

with $\mathrm{i}=1,2 . ., \mathrm{m}$ and $\mathrm{j}=1,2, \ldots ., \mathrm{n}$

Information :

$r_{i j}=$ Normalized performance rating

$x_{i j}=$ Value crips

$i=$ Suitability of alternative value of the criteria to $\mathrm{m}$

$j=$ Suitability of alternative value at every alternative to the $\mathrm{n}$

2) Creating a weighted normalized decision matrix.

$y_{i j}=\ldots$

With $\mathrm{i}=1,2, .,,, \mathrm{M}$ and $\mathrm{j}=1,2, ., ., \mathrm{N}$.

(2) $w_{i .} r_{i j}$

Information :

$y_{i j}+$ Ranking weights normalized

$w_{i}=$ Weight value preferences

3) Determining the ideal solution matrix of positive and negative ideal solution matrix. The ideal solution is positive () and negative ideal solution () can be determined based on the normalized weight rating () is as follows: (3) $A^{+} A^{-} y_{i j} A^{+}=\left(y_{1}{ }^{+}, y_{2}{ }^{+}, \ldots y_{n}{ }^{+}\right)$

$A^{-}=\left(y_{1}{ }^{-}, y_{2}{ }^{-}, \ldots y_{n}{ }^{-}\right)$

$A^{+}=$Solusi ideal positif $A^{-}=$Solusi ideal negatif

Where :

$y_{j}^{+}$is $=-$Max, if $\mathrm{j}$ is an attribute profits $y_{i j}$

- Min, if $\mathrm{j}$ is an attribute charge $y_{i j}$

$y_{j}^{-}$is $=-\quad$ Min $y_{i j}$ If $\mathrm{j}$ is an attribute profits

$\mathrm{j}=1,2, ., ., \mathrm{N}$

- Max, if $\mathrm{j}$ is an attribute charge $y_{i j}$

4) Determine the distance between the value of each alternative () with a positive ideal solution and the ideal solution negtif. $A_{i}$

The distance between the alternatives () with a positive ideal solution formulated as follows:

$$
\text { (4) } A_{i} D_{i}^{+}=\overline{{ }_{j}^{n}\left(y_{i}^{+}-y_{i j}\right)^{2}} ; \mathrm{i}=1,2, \ldots, \mathrm{m}
$$

Distance between alternatives $\left(A_{i}\right)$ With negative ideal solution formulated as follows:

$D_{i}^{+}=\overline{n_{j=i}^{n}\left(y_{i}^{-}-y_{i j}\right)^{2}} ; \mathrm{i}=1,2, \ldots, \mathrm{m}$

Information :

$$
\begin{aligned}
& D_{i}^{+}=\text {jarak antara alternatif } A_{i} \text { solusi ideal positi } \\
& D_{i}^{-}=\text {jarak antara alternatif } A_{i} \text { solusi ideal negatif }
\end{aligned}
$$

5) Determining the value of preference for each alternative () is formulated as follows: $V_{i}$

$$
V_{i}=\frac{D_{i}^{-}}{D_{i}^{-}+D_{i}^{+}}
$$

$\mathrm{i}=1,2, \ldots$,

Value $V_{i}$ Larger indicate that the preferred alternative. $A_{i}$

so the methodTechnique For Order Preference by Similarity to Ideal Solution(TOPSIS) is a model used to assist in the completion of the decision, especially in a state where a lot of goals or criteria are considered.

\section{Research methods}

\section{A. Framework Research}

The method used in this research is the method of flowchart. 


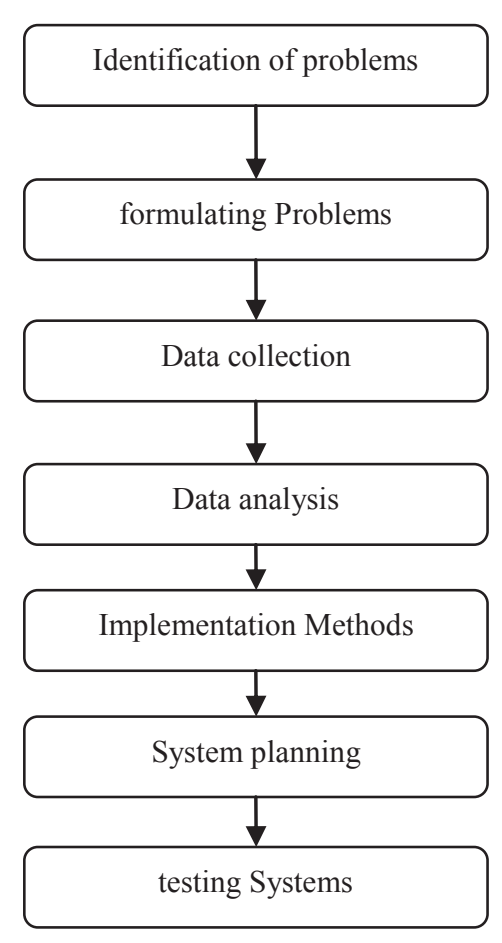

Fig 1. Framework Research

\section{B. Research sites} Sumatra

This research was conducted in Mahogany Way, Lubukpakam I / II Lubukpakam Deli Serdang North

\section{Case study}

The case studies carried out for research that is housed in at the Department of Public Works and Spatial Deli Serdang. In this case the researchers will observe or analyze the process of employee performance evaluation honoreruntuk help the Department of Public Works and pentaan space in improving the performance of permanent employees, the data information obtained from the Departments of Public Works and Spatial Planning and criteria determined in accordance with the conditions that existed at the Agency ttersebut. This research is compiled into the stages of preparation of the framework of the thesis, the selection of cases is done to develop the methods used.

\section{Analysis And Design}

\section{A. Analysis and Discussion}

In these discussions, do some steps to analyze and design systems aimed at determining the Honorary Employee Performance Assessment at the Department of Public Works and Spatial Deli Serdang by using Method Technique for Order Preference by Similarity to Ideal Solution (TOPSIS). So that the expected results of this study can be used for decision-making for Employee Performance Appraisal to be used as an alternative for agencies in determining employee performance appraisal results. To gather data, researchers used several techniques as follows:

There are five criteria in this study each criterion has a weight of preference based on importance of each criterion. The preference weights obtained from the Department of Public Works and Spatial temporary employee performance evaluation.

Table 1.

Criteria

\begin{tabular}{clc}
\hline Code & \multicolumn{1}{c}{ name Criteria } & Weight \\
\hline K1 & Work performance & 4 \\
K2 & Quality performance & 4 \\
K3 & performance discipline & 3 \\
K4 & Cooperation & 3 \\
K5 & Commitment & 3 \\
\hline
\end{tabular}

